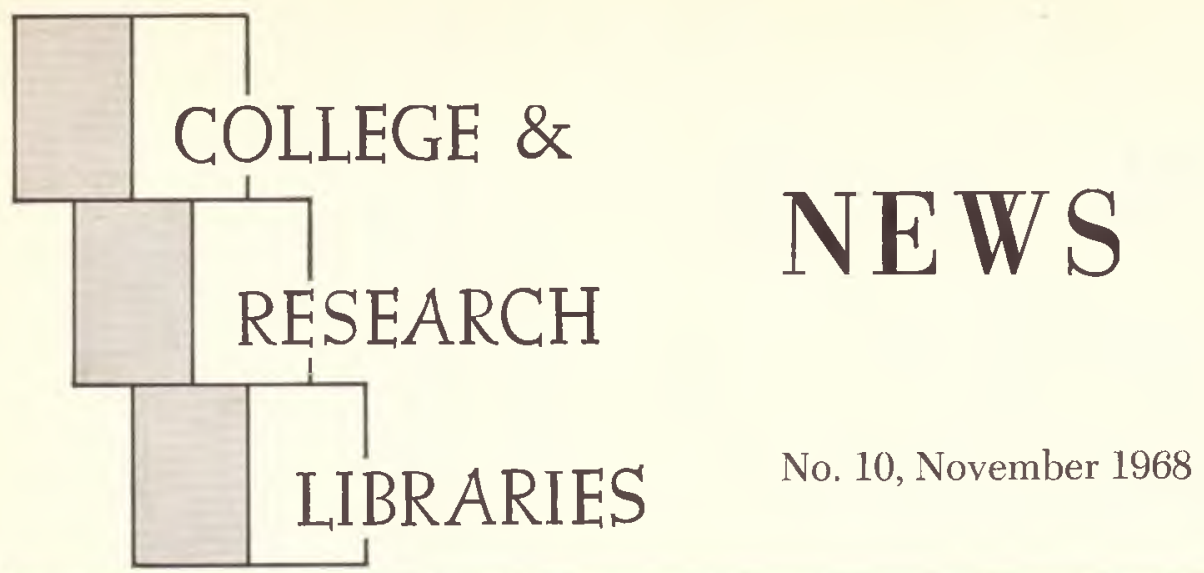

ACRL News Issue (A) of College \& Research Libraries, Vol. 29, No. 6

\title{
ALA Award Nominations
}

All ALA members are urged to recommend candidates for the association's awards, citations, and scholarships presented for distinguished service to the profession, publication, study and research. Most of the 1969 awards will be made during the ALA annual conference in Atlantic City. The chairman of the 1968-69 Awards Committee is Spencer G. Shaw, children's service consultant, The Nassau Library System.

BETA PHI MU AWARD-An annual award consisting of $\$ 50$ and a citation, administered by the Library Education Division, made to an individual for distinguished service to education for librarianship. Deadline for nominations, April 1, 1969. Send nominations to Chairman-Grace P. Slocum, Assistant Director, Enoch Pratt Free Library, 400 Cathedral Street, Baltimore, Maryland 21201.

MELVIL DEWEY MEDAL-An engraved medal and a citation presented annually to an individual or a group for recent creative professional achievement of a high order, particularly in those fields in which Melvil Dewey was actively interested, notably library management, library training, cataloging and classification, and the tools and techniques of librarianship. Donated by Forest Press, Inc. Deadline for nominations, January 15, 1969. Send five copies of nominations to the jury chairman-Allen B. Veaner, Assistant Librarian, Stanford University Libraries, Stanford, California 94305.

EXHIBITS ROUND TABLE AWARD-An annual award of $\$ 500$ made to an individual or a group to aid or improve some particular aspect of librarianship or library service on the basis of need in the profession or in the operation of professional library associations. Donated by Exhibits Round Table. ChairmanRichard N. Drysdale, Professional Library Service, $2200 \mathrm{E}$. McFadden Avenue, Santa Ana, California 92705.

HAMMOND INCORPORATED LIBRARY AWARD-An award of $\$ 500$ and a citation made annually to a librarian who has effectively encouraged the use of maps and atlases or promoted an interest in cartography. The award is to be presented only in those years when an appropriate recipient is found. Donated by Hammond Incorporated, Administered by ALÁ Awards Committee. Send nominations to the jury chairman by January 15, 1969. Chairman-Winifred M. Poole, Librarian, Laboratory High School Library, University of Chicago, 1362 East 59th Street, Chicago, Illinois 60637 .

JOSEPH W. LIPPINCOTT AWARD-An award consisting of $\$ 1000$, an engraved medal, and a special citation made annually to a librarian for distinguished service in the profession of librarianship, such service to include outstanding participation in the activities of professional library associations, notable published professional writing, or other significant activity in behalf of the profession and its aims. Donated by Joseph W. Lippincott. Administered by the ALA Awards Committee. Deadline for nominations: January 15, 1969. Chairman-Thomas R. Buckman, The University Library, Northwestern University, Evanston, Illinois 60201.

ISADORE GILBERT MUDGE CITATION -A citation to be given at the annual confer(Continued on page 340 ) 


\section{Our books are like everyone else's-but our Service is
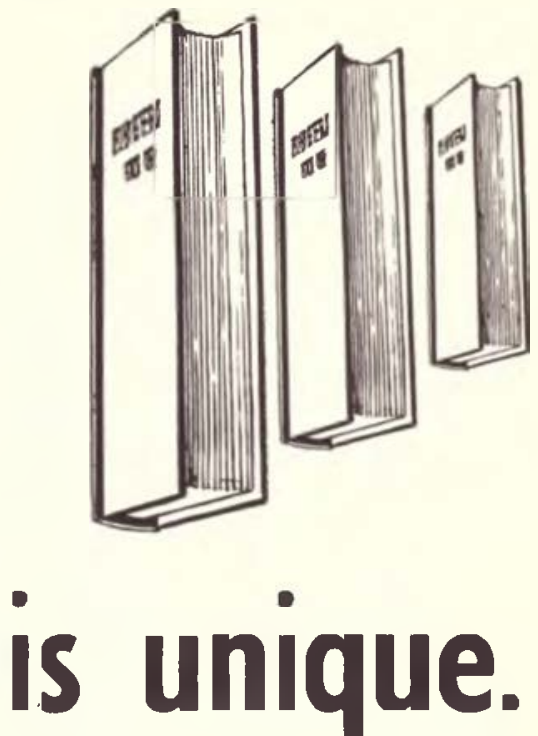

Yes, we specialize in service. For at Taylor-Carlisle, service is not just an expression. It is the mainstay of our policy, it is the actual reason for our existence, it is the one outstanding element that has meant so much to our clientele and contributed to our own continued growth. We supply books-but what we sell is service.

\section{Send for our brochure and terms.}
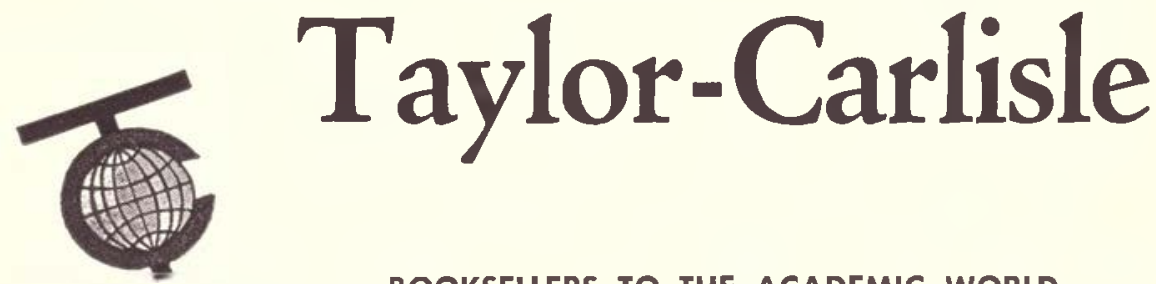

\section{BOOKSELLERS TO THE ACADEMIC WORLD}

NEW YORK: 115 East 23rd Street, New York, N.Y. 10010 FLORIDA: Winter Park Mall, Winter Park, Florida 32789 TEXAS: 1 Shell Plaza, Houston (Opening soon)

"Service" is the reason so many librarians order with confidence from Taylor-Carlisle. 


\section{AWARDS}

(Continued from page 337)

ence of the ALA to a person who has made a distinguished contribution to reference librarianship. This contribution may take the form of an imaginative and constructive program in a particular library; the writing of a significant book or articles in the reference field; creative and inspirational teaching of reference service; or other noteworthy activities which stimulate reference librarians to more distinguished performance. Send nominations to the chairman by March 15, 1969. Chairman-Wayne M. Hartwell, Librarian, Encyclopedia Britannica, 425 N. Michigan Avenue, Chicago, Illinois 60611.

EUNICE ROCKWELL OBERLY MEMORI$A L A W A R D-A$ biennial award given in oddnumbered years, consisting of a citation and a cash award of the income of the Oberly $\mathrm{Me}$ morial Fund, made to the American citizen who compiles the best bibliography in the field of agriculture or one of the related sciences in the two-year period preceding the year in which the award is made. Made possible by a fund established by colleagues in memory of Eunice Rockwell Oberly. Administered by ACRL Agriculture and Biological Sciences Subsection. Deadline for nominations, March 15, 1969. Send nominations to the committee chairman-Fleming Bennett, Hume Library, University of Florida, Gainesville, Florida 32601.

HALSEY W. WILSON LIBRARY RECRUITMENT AWARD-An annual award consisting of $\$ 1000$ to be given to any local, state, or regional library association, any library school, or any other appropriate group concerned with recruitment to the profession. (To be eligible, a state or regional library association must be a chapter of ALA.) There may be direct application or nomination for the award. The award will be made for the development of a sustained program of recruitment for librarianship and will be based on total continuing program, not limited to one year's activity. The criteria upon which selection will be based are: definition of goals; appropriateness and value to the library needs of an area in which the program is conducted; number of individuals entering library school or library employment; number and kind of individuals or groups reached; or other demonstrable results. The money comprising the award will be used for the continuation and further development of a recruitment program. Donated by H. W. Wilson Company. Administered by ALA Awards Committee. Deadline for nominations, January, 1969. Send five copies of the nominations to the jury chairman-Jessie C. Smith, Head Librarian, Fisk University Library, Nashville, Tennessee 37208.

H. W. WILSON LIBRARY PERIODICAL
AWARD - To be given annually to a periodical published by a local, state, regional library, library group, or library association in the United States or Canada which has made an outstanding contribution to librarianship. (This excludes publications of ALA, CLA, and their divisions.) All issues for the calendar year prior to the presentation of the award will be judged on the basis of sustained excellence in both content and format, with consideration being given to purpose and budget. The award shall be presented only in those years when a periodical meriting such recognition is submitted for the award. Donated by the H. W. Wilson Company. Administered by ALA Awards Committee. Deadline for nominations, January 15, 1969. Send nominations to the jury chairmanBen C. Bowman, Librarian, Hunter College Library, Hunter College, 695 Park Avenue, New York, New York 10021.

ESTHER J. PIERCY AWARD-An award, established in 1968, in the form of a citation given to recognize the contribution to librarianship in the field of the technical services by younger members of the profession. The recipient will be a librarian with not more than ten years of professional experience who has shown outstanding promise for continuing contributions and leadership in any of the fields comprising technical services by such means as (a) leadership in professional associations at local, state, regional or national levels; (b) contributions to the development, application, or utilization of new or improved methods, techniques, and routines; (c) a significant contribution to professional literature; (d) conduct of studies or research in the technical services. The award shall be given to an individual each year in which the Jury believes there to be a qualified recipient. Administered by the Resources and Technical Services Division. Deadline for nomination of candidates, January 13, 1969. Chairman-Mrs. Ruth F. Carnovsky, Associate Professor and Dean, Graduate Library School, University of Chicago, 1116 East 59th Street, Chicago, Illinois 60637 .

Herbert Putnam Honor Fund is an award of $\$ 500$ presented at intervals as a grant-in-aid to an American librarian of outstanding ability for travel, writing, or other use that might improve his or her service to the library profession or to society. The ALA Awards Committee serves as jury for this award. Nominations may be sent to Spencer G. Shaw, ALA Awards Committee, Nassau Library System, Lower Concourse, Roosevelt Field, Garden City, New York 11530.

SCARECROW PRESS AWARD FOR LIBRARY LITERATURE-An award of $\$ 500$ and a citation made to an American librarian to recognize an outstanding contribution to library literature issued during the calendar 
year preceding the presentation, donated by the Scarecrow Press and administered by ALA Awards Committee. Deadline for nominations is January 15, 1969. Send nominations to the jury chairman, Mrs. Virginia G. Young, Missouri State Library, State Office Building, Jefferson City, Missouri 65102.

\section{ACRL SECTION AND SUBSECTION COMMITTEE CHAIRMEN}

\section{COLLEGE LIBRARIES SECTION}

Nominating Committee, David Brunton, executive director, California Library Association; Non Western Resources, Mother E. O'Connor, Manhattanville College, Purchase, N.Y.; Steering Committee, Evan I. Farber, Earlham College, Richmond, Ind.

\section{JUNIOR COLLEGE LIBRARIES SECTION}

Instruction and Use, Richard L. Ducote, College of DuPage, Glen Ellyn, Ill.; Instructional Materials Center, James $O$. Wallace, San Antonio College, San Antonio, Tex.; Nominating CommitteE, Mrs. Ruth Riggs, Middlesex County College, Edison, N.J.; Preconference Committee, Mrs. Mayrelee Newman, El Centro College, Dallas, Tex.; Ad Hoc CommitTeE to Revise JCLS Bylaws, Ruth M. Christensen, California State College, Los Angeles; Special Projects Committee, Mrs. Alice B. Griffith, Mohawk Valley Community College, Utica, N.Y.

\section{RARE BOOKS SECTION}

Ad Hoc Commitiee on Manuscript ColLections, Mrs. Arline Custer, Library of Congress; Nominating Committee, J. William Matheson, Washington University, St. Louis, Mo. Standards Committee, Howard L. Applegate, Syracuse University (N.Y.); WonK MANual Subsection, Richard C. Berner, University of Washington, Seattle.

\section{SUBJECT SPECIALISTS SECTION}

Nominating Committee, Mary Frances Pinches, Case Western Reserve University, Cleveland, Ohio.

Agriculture and Biological Science

SUBSECTION

Nominating Committee; Richard T. Samuelson, Somerset County College, N.J.

Law and Political Science Subsection

Nominating Committee, Frances B. Woods, Yale University Law School, New Haven, Conn.; Committee on Model Law Collections, Roy Mersky, University of Texas School of Law, Austin.

Slavic and East European Subsection

Nominating Committee, Bohdan Wynar, State University College, Geneseo, N.Y.

\section{UNIVERSITY LIBRARIES SECTION}

An Hoc Commttee on Academic Status, Lewis C. Branscomb, Ohio State University, Columbus; CommitTeE on Extension Library Service, Frank C. MacDougall, Michigan State University, East Lansing; Nominating CoMMITTEE, Gustave A. Harrer, University of Florida, Gainesville; Research and DevelopMENT, Earl Farley, University of Kansas, Kansas City; Steering Committee, G. F. Shepherd, Jr., Cornell University Libraries, Ithaca, N.Y.; Urban Universities Library CommitTEE, Bernard Kreissman, City College of the City University of New York.

\section{APPRENTICE SURVEYORS}

Well qualified library surveyors are not plentiful, and the ACRL Committee on Librars Surveys would like to increase the supply. One of the best means of learning how to survey libraries is to make surveys. Indeed, experience is so obviously desirable that the persons invited to do work of this kind usually are already successful and experienced surveyors. The problem is obvious: How does one start? How can the beginner acquire experience?

The committee strongly recommends that. whenever practicable, surveys be made by a team rather than by a single individual, and that each team include an "apprentice" surveyor who has never directed a library survey.

The committee hopes to be able to suggest to the directors of surveys names of persons who may be interested in serving as apprentices. In order to do this it needs to know who is interested in surveying junior college, college, university, and other research libraries. This is an invitation to supply the information that is needed:

All persons interested in working as apprentice surveyors are asked to summarize their educational preparation and professional positions held to date, to give present position and address, to describe any particularly relevant special qualifications or experience, and to indicate interests or specialties-i.e., type of college or research library or field such as administration, automation, collections, public services, technical services, etc. Correspondence should be addressed to Edwin E. Williams, Chairman ACRL Committee on Library Surveys, Widener Library 183, Harvard University, Cambridge, Massachusetts 02138.

In 1964 the committee attempted to compile a roster of experienced surveyors, and it would also welcome correspondence from persons who have directed surveys and would like to have their names added to that roster. 